\title{
A collaborative exercise on DNA methylation-based body fluid typing
}

\author{
Sang-Eun Jung ${ }^{1}$, Sohee $\mathrm{Cho}^{2}$, Joana Antunes ${ }^{3}$, Iva Gomes ${ }^{4}$, Mari L. Uchimoto ${ }^{5}$, Yu Na $\mathrm{Oh}^{6}$, \\ Lisa Di Giacomo ${ }^{4}$, Peter M. Schneider ${ }^{4}$, Min Sun Park ${ }^{7}$, Dieudonne van der Meer ${ }^{5}$, Graham \\ Williams ${ }^{5}$, Bruce McCord ${ }^{3}$, Hee-Jung Ahn ${ }^{6}$, Dong Ho Choi ${ }^{7}$, Yang-Han Lee ${ }^{7}$, Soong Deok \\ Lee $^{2}$, Hwan Young Lee ${ }^{1, *}$
}

${ }^{1}$ Department of Forensic Medicine, Yonsei University College of Medicine, Seoul, Korea ${ }^{2}$ Department of Forensic Medicine, Seoul National University College of Medicine, Seoul, Korea

${ }^{3}$ Department of Chemistry and Biochemistry, Florida International University, Miami, USA ${ }^{4}$ Institute of Legal Medicine, Faculty of Medicine, University of Cologne, Cologne, Germany

${ }^{5}$ Forensic and Analytical Research Centre, University of Huddersfield, Queensgate, Huddersfield, West Yorkshire, United Kingdom

Received: 01-06-2016; Revised: 01-06-2016; Accepted: 10-07-2016

This article has been accepted for publication and undergone full peer review but has not been through the copyediting, typesetting, pagination and proofreading process, which may lead to differences between this version and the Version of Record. Please cite this article as doi: 10.1002/elps.201600256. 
${ }^{6}$ Division of DNA Analysis, Department of Forensic Medicine, Scientific Investigation Laboratory, Criminal Investigation Command, Ministry of National Defense, Seoul, Korea

${ }^{7}$ Forensic DNA Division, National Forensic Service, Wonju, Gangwon-do, Korea

*Correspondence: Hwan Young Lee, Department of Forensic Medicine, Yonsei University College of Medicine, 50-1 Yonsei-ro, Seodaemun-gu, Seoul 03722, South Korea E-mail: hylee192@yuhs.ac, hylee192@gmail.com

Fax: +82-2-362-0860

Abbreviation: PCR, polymerase chain reaction

Keywords: body fluid identification / collaborative exercise / DNA methylation / forensic science / methylation SNaPshot

Total number of words: 5,000

This article is protected by copyright. All rights reserved. 


\begin{abstract}
A collaborative exercise on DNA methylation-based body fluid identification was conducted by seven laboratories. For this project, a multiplex methylation SNaPshot reaction composed of seven CpG markers was used for the identification of 4 body fluids, including blood, saliva, semen and vaginal fluid. A total of 30 specimens were prepared and distributed to participating laboratories after thorough testing. The required experiments included four increasingly complex tasks: 1) capillary electrophoresis of a purified single-base extension reaction product, 2) multiplex PCR of bisulfite-modified DNA, 3) bisulfite conversion of genomic DNA and 4) extraction of genomic DNA from body fluid samples. In tasks 2, 3 and 4, one or more mixtures were analyzed, and specimens containing both known and unknown body fluid sources were used. Six of the laboratories generated consistent body fluid typing results for specimens of bisulfite converted DNA and genomic DNA. One laboratory failed to set up appropriate conditions for capillary analysis of reference single-base extension products. In general, variation in the values obtained for DNA methylation analysis between laboratories increased with the complexity of the required experiments. However, all laboratories concurred on the interpretation of the DNA methylation profiles produced. Although the establishment of interpretational guidelines on DNA methylation-based body fluid identification has yet to be performed, this study supports the addition of DNA methylation profiling to forensic body fluid typing.
\end{abstract}

This article is protected by copyright. All rights reserved. 


\section{Introduction}

Body fluid identification can be of significant importance in solving crimes by assisting the triers of fact in the determination of potential scenarios that may have led to the deposition of evidentiary material [1]. Recently, molecular approaches that permit the detection of specific messenger RNA (mRNA) and micro RNA (miRNA) expression as well as differential DNA methylation patterns have been intensively investigated [2]. Among these, the mRNA-based detection methods have been the most scrutinized, and performance in terms of reproducibility and sensitivity has been well evaluated through a series of large collaborative exercises [2-8].

DNA methylation-based body fluid identification has many advantages when compared to mRNA-based methods, such as higher specificity, the ability to be inserted into current forensic DNA-based testing protocols, and the applicability to old cases where only DNA extracts are available [9]. Many CpG markers have been identified which produce differential DNA methylation patterns when extracted DNA from body fluids are compared using genome-wide profiling and gene-specific analysis [10-15]. Three recent publications [13-15] are particularly notable for reporting a set of $\mathrm{CpG}$ markers that show a methylation signal only in the target body fluids, which can be beneficial to mixed sample analysis. In particular, two earlier studies $[13,14]$ reported two markers in common; cg17610929, suggested to distinguish semen and cg06379435, for blood. Moreover, further analysis of array data from

This article is protected by copyright. All rights reserved. 
the two studies revealed that they had another blood-specific marker, cg08792630, in common. Because the identification and use of semen-specific $\mathrm{CpG}$ markers is not a problem due to the significant difference in DNA methylation between somatic cells and germ cells, further validation studies of CpGs specific to other body fluids, such as vaginal fluid, menstrual blood, saliva etc., would be needed for better application of DNA methylation analysis in forensic caseworks. To detect DNA methylation levels at multiple $\mathrm{CpG}$ sites simultaneously, methylation-sensitive restriction enzyme-PCR (MSRE-PCR) and the methylation-sensitive single nucleotide primer extension (SNuPE)-based approach, generally called methylation SNaPshot, have been utilized $[10,14,15]$. In comparison to MSRE-PCR, methylation SNaPshot reactions provide better resolution, and have been adopted in more recent studies [14-16].

The present collaborative exercise was organized by Yonsei University College of Medicine in order to evaluate the robustness and reproducibility of DNA methylation profiling for body fluid identification in seven forensic laboratories using kits and chemistries of their own choice and using their own instrumentation. The multiplex methylation SNaPshot reaction used by the collaborative laboratories described in [14] was modified to include seven $\mathrm{CpG}$ markers that show a methylation signal only in the target body fluids. Since the participating laboratories had varying levels of experience, especially with DNA methylation profiling using bisulfite conversion and with the SNaPshot reaction, the goal was to implement the method and compare the interpretational results of DNA methylation profiling from the various laboratories.

This article is protected by copyright. All rights reserved. 


\section{Materials and methods}

\subsection{Samples and materials provided}

The exercise was divided into four parts such that participants could easily check the success of experiments performed after each step of the consecutive procedures (Table 1). Part 1 involved the capillary electrophoresis of purified single-base extension (SBE) reaction products, part 2 involved multiplex PCR of bisulfite converted DNA, part 3 involved the bisulfite conversion of genomic DNA and part 4 involved the DNA extraction of body fluid samples. As such, the complexity of the required experiments increased as the participants proceeded through each part. Specimens, including blood, saliva, semen, vaginal fluid, and menstrual blood, were collected from seven healthy volunteers using procedures approved by the Institutional Review Board of Severance Hospital, Yonsei University in Seoul, Korea. Blood was collected by venipuncture with a syringe, and $200 \mu \mathrm{L}$ aliquots from EDTA containing tubes were stored frozen at $-20^{\circ} \mathrm{C}$. Saliva samples were collected with the Oragene $^{\mathrm{TM}}$ DNA self-collection kit (DNA Genotek Inc., Ottawa, Canada), and stored at ambient temperature. Freshly ejaculated semen was collected in plastic cups, and $200 \mu \mathrm{L}$ aliquots were frozen at $-20^{\circ} \mathrm{C}$ for storage. Vaginal fluid and menstrual blood were collected using sterile cotton swabs and allowed to dry at room temperature. The eight body fluid specimens used in part 4 included four single source samples and one mixture of indicated

This article is protected by copyright. All rights reserved. 
origin, and two single source samples and one mixture of unspecified origin. One hundred and twenty microliter of freshly ejaculated semen and blood were prepared separately in an eppendorf microfuge tube with indicated origin. A $200 \mu \mathrm{L}$ of saliva sample was prepared in the Oragene ${ }^{\mathrm{TM}}$ DNA self-collection kit buffer with indicated origin. Two vaginal swabs and a menstrual blood swab were obtained from a volunteer. From the two vaginal swabs obtained from a volunteer, one was spiked with $70 \mu \mathrm{L}$ of semen and both were provided to the collaborative laboratories with an indication of their origin. The menstrual blood swab was sent to the collaborative laboratories with unspecified origin. A semen swab was prepared by dropping $100 \mu \mathrm{L}$ of semen on a sterile cotton swab, and was provided to the collaborative laboratories with unspecified origin. A body fluid mixture swab was prepared by adding 100 $\mu \mathrm{L}$ solution of blood, saliva and semen mixed in a ratio of $2: 1: 1.5$ on a sterile cotton swab and was provided to the collaborative laboratories with unspecified origin. Treated swabs were allowed to dry at room temperature and stored at $-80^{\circ} \mathrm{C}$ until sent to participating laboratories.

For parts 2 and 3, $100 \mathrm{ng}$ of bisulfite converted DNA and $200 \mathrm{ng}$ of genomic DNA were prepared for five single source samples with an indicated source of origin, two single source samples of unspecified origin, and one mixture of unspecified origin. To prepare mixtures in parts 2 and 3, the same concentration of each bisulfite converted DNA (from blood and saliva) or genomic DNA (from semen and vaginal fluid) were mixed in a ratio of 1:1.

This article is protected by copyright. All rights reserved. 
For part 1, the final products from the methylation SNaPshot reaction obtained from one sample each of semen, blood, vaginal fluid and saliva, and two samples from menstrual bloods were prepared as reference materials.

All samples and PCR primer mixtures were thoroughly tested prior to shipment and sent to participating laboratories on dry ice taking from one to four days. When requested, additional reagents such as SNaPshot kit (Applied Biosystems, Foster City, CA, USA) or enzymes necessary for PCR product purification, SBE reaction and purification were sent together on dry ice, and the Imprint ${ }^{\mathrm{TM}}$ DNA Modification kit (Sigma-Aldrich, St. Louis, MO, USA) for bisulfite conversion was sent at room temperature.

\subsection{DNA extraction, DNA quantification and bisulfite conversion}

In the organizing laboratory, samples were subjected to DNA extraction, quantification and sodium bisulfite treatment. DNA was extracted from each aliquot of blood, saliva, and semen or from each swab of vaginal fluid and menstrual blood using a QIAamp ${ }^{\circledR}$ DNA Mini kit (Qiagen, Hilden, Germany) following the manufacturer's instructions. Extracted DNA was quantified using a Quantifiler ${ }^{\circledR}$ Duo DNA Quantification kit (Applied Biosystems), and 200 ng of genomic DNA was bisulfite converted using the Imprint ${ }^{\mathrm{TM}}$ DNA Modification kit and eluted with $20 \mu \mathrm{L}$ of distilled water. For preparation of specimens to send to collaborative laboratories, an appropriate number of genomic DNA and bisulfite converted DNA batches were pooled and redistributed into $10 \mu \mathrm{L}$ aliquots, which contained $20 \mathrm{ng} / \mu \mathrm{L}$ of genomic

This article is protected by copyright. All rights reserved. 
DNA or approximately $10 \mathrm{ng} / \mu \mathrm{L}$ of bisulfite converted DNA. The specified genomic DNA input in bisulfite conversion of part 3 was $100 \mathrm{ng}$ of genomic DNA, but in part 4, the input amount was not suggested. Example protocols were provided to participating laboratories (Supplementary Material 1) as a reference, but the chemistries and instrumentation to be used were left for each laboratory to decide.

\subsection{Multiplex methylation SNaPshot}

The multiplex methylation SNaPshot reaction described in [14] was modified to include seven $\mathrm{CpG}$ markers that show a methylation signal only in the target body fluids. For this study, a blood marker, $\operatorname{cg} 01543184$, with cross reactivity to semen was replaced with blood marker cg08792630 [13], and a semen marker cg17621389 with that produced semenspecific non-methylation was removed. The resultant multiplex included two CpGs (SE1 and SE2) for semen, two CpGs (BL1 and BL3) for blood, two CpGs (VF1 and VF2) for vaginal fluid and one CpG (SA1) for saliva (Supplementary Material 1); SE1, SE2, BL1, BL3, VF1, VF2, and SA1 represent cg17610929, cg26763284, cg06379435, cg08792630, cg09765089231d, cg26079753-7d, and cg09652652-2d, respectively. The multiplex PCR was performed in $20 \mu \mathrm{L}$ reactions containing $1 \mu \mathrm{L}$ of bisulfite-converted DNA (10 ng), $3 \mathrm{U}$ of AmpliTaq Gold $^{\circledR}$ DNA polymerase, $2 \mu \mathrm{L}$ of Gold ST*R 10× buffer (Promega, Madison, WI, USA), and PCR primers (Supplementary material 1). PCR cycling was conducted using a Veriti ${ }^{\mathrm{TM}}$ Thermal Cycler (Applied Biosystems) under the following conditions: $95^{\circ} \mathrm{C}$ for $11 \mathrm{~min} ; 34$

This article is protected by copyright. All rights reserved. 
cycles of $94^{\circ} \mathrm{C}$ for $20 \mathrm{~s}, 56^{\circ} \mathrm{C}$ for $60 \mathrm{~s}$, and $72^{\circ} \mathrm{C}$ for $30 \mathrm{~s}$; and a final extension at $72^{\circ} \mathrm{C}$ for 7 $\min$. Then, $5 \mu \mathrm{L}$ of PCR products were purified with $1 \mu \mathrm{L}$ of ExoSAP-IT (USB, Cleveland, $\mathrm{OH}, \mathrm{USA}$ ) by incubation at $37^{\circ} \mathrm{C}$ for $45 \mathrm{~min}$ followed by heat inactivation at $80^{\circ} \mathrm{C}$ for $15 \mathrm{~min}$. Multiplex SBE reaction was performed using $1 \mu \mathrm{L}$ of purified PCR products, SBE primers (Supplementary Material 1) and a SNaPshot ${ }^{\mathrm{TM}}$ kit according to the manufacturer's instructions. The final extension products were purified with SAP-Recombinant (USB) enzyme. Large batch of $5 \times$ PCR primer and 10× SBE primer stocks were prepared and aliquoted to provide all laboratories with the same primer mixtures. The specified bisulfite converted DNA input for the multiplex PCR of parts 2 and 3 was $10 \mathrm{ng}$; in part 4, the input amount was not suggested. Example protocols were provided to participating laboratories (Supplementary Material 1), but a choice was given regarding which PCR buffers and amplicon purification methods were to be used.

\subsection{Capillary electrophoresis and analysis of DNA methylation profiles}

In the organizing laboratory, the extension products were analyzed using the ABI PRISM 3130xl Genetic Analyzer and GeneScan software 3.1 (Applied Biosystems). In participating laboratories, samples were injected and run according to conditions of choice on various types of standard genetic analyzers (Supplementary material 2). For the analysis of DNA methylation profiles, participating laboratories were requested to report peak heights observed from the electropherograms and to calculate percentage methylation values $(0-$

This article is protected by copyright. All rights reserved. 
$100 \%$ ) at each CpG site by dividing nucleotide G intensity (detection of unconverted methylated cytosine on the reverse strand) by nucleotide $\mathrm{G}$ plus nucleotide A intensity (detection of converted unmethylated cytosine on the reverse strand). Then, body fluid typing results were reported in reference to the electrophoretic results of SBE products in part 1.

\section{Results and Discussion}

\subsection{Participating laboratories}

Seven laboratories including the organizing laboratory participated in this exercise. The participating laboratories varied in experience with regard to DNA methylation analyses. Two laboratories indicated they were beginners at DNA methylation testing; two other laboratories, advanced beginners; one laboratory, an experienced researcher; and two other laboratories, experts. The participating laboratories were also asked to complete a questionnaire describing the kits, chemicals, quantities and instrumentation they used (Supplementary material 2). The seven laboratories used four different kits for DNA extraction, five different quantification methods, two different kits for bisulfite conversion, two different PCR buffers for multiplex PCR, three different thermocyclers, three different genetic analyzers and three different analytical software and five different analytical settings. The diversity of instrumentation and respective analysis tools emphasizes the importance of

This article is protected by copyright. All rights reserved. 
such collaborative exercises in order to evaluate the robustness of implementation of methods in different laboratories.

\subsection{Exercise tasks: parts 1 to 4}

The collaborative exercise started with part 1, where purified SBE products are analyzed with capillary electrophoresis. Analysis of the final multiplex methylation SNaPshot products from various body fluid samples provided references to the following data interpretation and enabled adjustment of the genetic analyzer setting if necessary. Six of the seven laboratories reported very similar results in part 1 (Fig. 1). One laboratory (laboratory 4) had, on average, 4-fold higher peaks than the organizing laboratory with low non-specific peaks that seemed to be due to the use of higher injection settings. Because of failure in adjusting the genetic analyzer setting and unsuccessful enzyme treatment to purify PCR products in the subsequent parts 2-4 at laboratory 4, the results discussed in this report will only include data from the remaining six laboratories. The methylation percentages at each $\mathrm{CpG}$ site were similar among the laboratories, but two laboratories using an ABI PRISM 310 genetic analyzer showed somewhat lower methylation percentages. In addition, it seems that because two types of menstrual blood of which one had the same profile as vaginal fluid (menstrual blood type 1) were provided as references in part 1, participating laboratories had difficulty in inferring the sample origin with the profile of vaginal fluid; in this case, some laboratories reported the origin of the sample to be either vaginal fluid or menstrual blood, while others reported it to

This article is protected by copyright. All rights reserved. 
be vaginal fluid or menstrual blood (Supplementary Material 3). As such, a distinction between vaginal fluid and menstrual blood could not be provided for the reports regarding parts $2-4$.

In part 2, bisulfite converted genomic DNA of semen, blood, vaginal fluid, menstrual blood and saliva with known body fluid origin, and three other samples with unspecified origin of which two were single source and one was a mixture, allowed us to test the proficiency of the participating laboratories in performing the SNaPshot reaction. Four of the six laboratories reported methylation signals only at target body fluid-specific $\mathrm{CpG}$ markers with correct body fluid typing results (Fig. 2). Two laboratories reported additional low level methylation signals at SE1, BL1 and SA1 markers, but these results did not affect correct interpretation of the body fluid typing results (Supplementary Material 3). These signals had low methylation percentages, mostly less than $15 \%$. For example, the two lowest methylation signals from laboratory 6 were $100 \mathrm{rfu}$ and $94 \mathrm{rfu}$ corresponding to $6.7 \%$ and $8.1 \%$ methylation percentages at BL1 and SA1 CpG sites, respectively. Therefore, all six laboratories properly performed and implemented the multiplex SNaPshot reactions with 10 ng of bisulfite converted DNA.

For part 3, genomic DNA from semen, blood, vaginal fluid, menstrual blood and saliva and three genomic DNA samples of unspecified origin were provided to test each laboratory's proficiency in bisulfite conversion. The participating laboratories were asked to treat $100 \mathrm{ng}$ of genomic DNA with a bisulfite conversion kit of choice and to perform multiplex methylation SNaPshot reactions with a 1/10 portion of the eluted bisulfite

This article is protected by copyright. All rights reserved. 
converted DNA. Two kits were used in bisulfite conversion (Supplementary material 2), but no significant difference was observed between the results. As in part 2, the same four laboratories reported methylation signals only at target body fluid-specific $\mathrm{CpG}$ markers with correct body fluid typing results (Fig. 3). Two laboratories (laboratories 5 and 6) reported sporadic methylation signals at the BL1 or BL3 markers in semen, menstrual blood and in the mixture of semen and vaginal fluid. These peaks were generally low in methylation percentage, i.e. less than $15 \%$, and did not affect the correct interpretation of body fluid typing results. However, the methylation percentages at each target $\mathrm{CpG}$ site showed higher variation among laboratories in part 3 when comparing to parts 1 and 2. Laboratory 3 reported no signal at the BL3 marker in a sample that was most likely a result of PCR failure at this site; however, it did not affect the identification of body fluid type. In addition, laboratory 6 reported a high methylation percentage (35.6\%) at the BL1 site in the mixture of semen and vaginal fluid, leading to a body fluid typing result of a mixture of semen and menstrual blood (Supplementary Material 3). In most cases, laboratories concurred on the expected interpretation of the results reported among them with genomic DNA and bisulfite converted DNA. This result suggests that DNA methylation-based body fluid identification using multiplex methylation SNaPshot and bisulfite conversion of genomic DNA could be successfully incorporated into forensic laboratory workflow.

In part 4, various body fluid samples with and without specified origin were provided. Specimens were subjected to DNA extraction, quantification, bisulfite conversion and multiplex methylation $\mathrm{SNaPshot} \mathrm{reaction} \mathrm{using} \mathrm{various} \mathrm{methodologies} \mathrm{according} \mathrm{to} \mathrm{each}$

This article is protected by copyright. All rights reserved. 
laboratory's preference. Three DNA extraction kits and four quantification methods were used by the six different laboratories. Sufficient amounts of DNA were obtained from most of the laboratories, but relatively small yields of DNA were obtained in one of the laboratories using an automatic DNA extraction system (laboratory 6). Various amounts of DNA were subjected to bisulfite conversion and $1 / 10$ or $1 / 20$ of the volume of eluted bisulfite converted DNA was amplified in a subsequent multiplex methylation SNaPshot reaction. The resultant amplified bisulfite converted DNA varied in amount from $0.8 \mathrm{ng}$ to $20 \mathrm{ng}$. Of the six laboratories being evaluated, five laboratories produced acceptable results with the correct body fluid identification. The sixth laboratory (laboratory 5) failed to obtain electrophoretic results from a few specimens but produced correct results from the others (Supplementary Material 3). The five laboratories reported methylation signals only at target body fluidspecific CpG markers except for a menstrual blood swab with unspecified origin (Fig. 4). For this sample, laboratory 6 produced unexpected methylation signals at SE1 and BL1 CpG markers, and laboratory 7 showed methylation signals at BL1 and BL3 CpG markers. However, these methylation signals were all less than $10 \%$, and had no adverse effect on data interpretation since both laboratories reported the specimens to be either vaginal fluid or menstrual blood. Laboratory 5 did not get body fluid typing results from three samples with indicated origin. Since certain amounts of DNA were extracted and quantified from these three samples, failure seems to have occurred in the recovery of bisulfite converted DNA or in PCR amplification. This laboratory also reported "inconclusive" for a mixture swab with a methylation signal only at SE1, BL3 and SA1. However, additional low methylation signals

This article is protected by copyright. All rights reserved. 
at SE2 and BL1 ( 50 rfu) (data not shown) suggested the presence of semen, blood and saliva in this sample. In this exercise, the most experienced laboratories produced better DNA methylation profiles and interpretation results. However, even the laboratories that varied from less experienced to beginners in DNA methylation analysis produced successful body fluid typing results, providing strong evidence for the potential application of DNA methylation profiling for use in forensic body fluid typing.

\section{Concluding remarks}

This collaborative exercise aimed to examine the possibility of incorporating DNA methylation-based body fluid identification methods into forensic case-work workflow. Most of the participating laboratories reported consistent results for mixtures as well as for single source samples with the use of their own laboratory equipment and different kits and chemicals of choice, which demonstrate the usefulness of this application of DNA methylation profiling in forensic body fluid typing. In this study, we found that certain laboratories reported low but detectable methylation signals at unexpected $\mathrm{CpG}$ sites, and there were variations in DNA methylation percentages among laboratories. Because these unexpected methylation signals were frequently at less than $10 \%$ methylation and sometimes lower than $100 \mathrm{rfu}$, we recommend that in the future an appropriate detection threshold in terms of rfu and percent of methylation, e.g., more than $100 \mathrm{rfu}$ and $10 \%$ methylation, should be applied. As for the methylation variation, this is not an unexpected result given that the

This article is protected by copyright. All rights reserved. 
participating laboratories used a variety of methods and instrumentation. It is important to note that the seven CpGs used in this multiplex provide on-off signal variations in results that can alleviate the effect of methylation variation among laboratories. Because it is not possible to differentiate vaginal fluid and menstrual blood with the present multiplex methylation SNaPshot system, the addition of new menstrual blood-specific $\mathrm{CpG}$ markers to the multiplex system is needed for better identification of body fluids. In addition, with the use of two or more $\mathrm{CpG}$ markers for each target body fluid being preferred, it is evident that there is also a need to identify more CpGs that are specific to saliva. If possible, the multiplex system should be supplemented in the future with more $\mathrm{CpG}$ markers to have two or more $\mathrm{CpGs}$ for each body fluid and consequently increase the accuracy of the identification of body fluids. While routine use of DNA methylation-based body fluid typing and identification assays may yet require further tests for sensitivity and specificity, this study demonstrates that methylation profiling can be successfully implemented in forensic laboratories once clear guidelines are set for data interpretation.

This article is protected by copyright. All rights reserved. 


\section{Acknowledgements}

This research was supported by the Ministry of Public Administration and Security, Republic of Korea through the National Forensic Service (Grant nos. 1315000435 and 1315000544).

B. McCord and J. Antunes were supported in part through funding provided by award 2012D1-BX-K018 from the National Institute of Justice, USA. Points of view in the document are those of the authors and do not necessarily represent the official view of the U.S. Department of Justice.

\section{Conflicts of interest statement}

The authors declare that they have no conflicts of interest.

This article is protected by copyright. All rights reserved. 


\section{References}

[1] Virkler, K., Lednev I. K., Forensic Sci. Int. 2009, 188, 1-17.

[2] Sijen, T., Forensic Sci. Int. Genet. 2015, 18, 21-32.

[3] Haas, C., Hanson, E., Bär, W., Banemann, R., Bento, A, M., Berti, A., Borges, E., Bouakaze, C., Carracedo, A., Carvalho, M., Choma, A., Dötsch, M., Durianciková, M., Hoff-Olsen, P., Hohoff, C., Johansen, P., Lindenbergh, P. A., Loddenkötter, B., Ludes, B., Maroñas, O., Morling, N., Niederstätter, H., Parson, W., Patel, G., Popielarz, C., Salata, E., Schneider, P. M., Sijen, T., Sviezená, B., Zatkalíková, L., Ballantyne, J., Forensic Sci. Int. Genet. 2011, 5, 21-26.

[4] Haas, C., Hanson, E., Anjos ,M. J., Bär, W., Banemann, R., Berti, A., Borges, E., Bouakaze, C., Carracedo, A., Carvalho, M., Castella, V., Choma, A., De Cock, G., Dötsch, M., Hoff-Olsen, P., Johansen, P., Kohlmeier, F., Lindenbergh, P. A., Ludes, B., Maroñas, O., Moore, D., Morerod, M. L., Morling, N., Niederstätter, H., Noel, F., Parson, W., Patel, G., Popielarz, C., Salata, E., Schneider, P. M., Sijen, T., Sviežena, B., Turanská, M., Zatkalíková, L., Ballantyne, J., Forensic Sci. Int. Genet. 2012, 6, $70-80$.

[5] Haas, C., Hanson, E., Anjos, M. J., Banemann, R., Berti, A., Borges, E., Carracedo, A., Carvalho, M., Courts, C., De Cock, G., Dötsch, M., Flynn, S., Gomes, I., Hollard,

This article is protected by copyright. All rights reserved. 
C., Hjort, B., Hoff-Olsen, P., Hríbiková, K., Lindenbergh, A., Ludes, B., Maroñas, O., McCallum, N., Moore, D., Morling, N., Niederstätter, H., Noel, F., Parson, W., Popielarz, C., Rapone, C., Roeder, A. D., Ruiz, Y., Sauer, E., Schneider, P. M., Sijen, T., Court, D. S., Sviežená, B., Turanská, M., Vidaki, A., Zatkalíková, L., Ballantyne, J., Forensic Sci. Int. Genet. 2013, 7, 230-239.

[6] Haas, C., Hanson, E., Anjos, M. J., Ballantyne, K. N., Banemann, R., Bhoelai, B., Borges, E., Carvalho, M., Courts, C., De Cock, G., Drobnic, K., Dötsch, M., Fleming, R., Franchi, C., Gomes, I., Hadzic, G., Harbison, S. A., Harteveld, J., Hjort, B., Hollard, C., Hoff-Olsen, P., Hüls, C., Keyser, C., Maroñas, O., McCallum, N., Moore, D., Morling, N., Niederstätter, H., Noël, F., Parson, W., Phillips, C., Popielarz, C., Roeder, A. D., Salvaderi, L., Sauer, E., Schneider, P. M., Shanthan, G., Court, D. S., Turanská, M., van Oorschot, R. A., Vennemann, M., Vidaki, A., Zatkalíková, L., Ballantyne, J., Forensic Sci. Int. Genet. 2014, 8, 203-212.

[7] van den Berge, M., Carracedo, A., Gomes, I., Graham, E. A., Haas, C., Hjort, B., Hoff-Olsen, P., Maroñas, O., Mevåg, B., Morling, N., Niederstätter, H., Parson, W., Schneider, P. M., Court, D. S., Vidaki, A., Sijen, T., Forensic Sci. Int. Genet. 2014, $10,40-48$.

[8] Haas, C., Hanson, E., Banemann, R., Bento, A. M., Berti, A., Carracedo, Á., Courts, C., De Cock, G., Drobnic, K., Fleming, R., Franchi, C., Gomes, I., Hadzic, G., Harbison, S. A., Hjort, B., Hollard, C., Hoff-Olsen, P., Keyser, C., Kondili, A., Maroñas, O., McCallum, N., Miniati, P., Morling, N., Niederstätter, H., Noël, F.,

This article is protected by copyright. All rights reserved. 
Parson, W., Porto, M. J., Roeder, A. D., Sauer, E., Schneider, P. M., Shanthan, G., Sijen, T., Syndercombe, Court D., Turanská, M., van den Berge, M., Vennemann, M., Vidaki, A., Zatkalíková, L., Ballantyne, J., Forensic Sci. Int. Genet. 2015, 16, 139147.

[9] An, J. H., Shin, K. J., Yang, W. I., Lee, H. Y., BMB Rep. 2012, 45, 545-553.

[10] Frumkin, D., Wasserstrom, A., Budowle, B., Davidson, A., Forensic Sci. Int. Genet. $2011,5,517-524$.

[11] Lee, H. Y., Park, M. J., Choi, A., An, J. H., Yang, W. I., Shin, K. J., Int. J. Legal Med. $2012,126,55-62$.

[12] Madi, T., Balamurugan, K., Bombardi, R., Duncan, G., McCord, B., Electrophoresis 2012, 33, 1736-1745.

[13] Park, J. L., Kwon, O. H., Kim, J. H., Yoo, H. S., Lee, H. C., Woo, K. M., Kim, S. Y., Lee, S. H., Kim, Y.S., Forensic Sci. Int. Genet. 2014, 13, 147-153.

[14] Lee, H. Y., An, J. H., Jung, S. E., Oh, Y. N., Lee, E.Y., Choi, A., Yang, W. I., Shin, K. J., Forensic Sci. Int. Genet. 2015, 17, 17-24.

[15] Forat, S., Huettel, B., Reinhardt, R., Fimmers, R., Haidl, G., Denschlag, D., Olek, K., PLoS One 2016, 11, e0147973.

This article is protected by copyright. All rights reserved. 
[16] An, J. H., Choi, A., Shin, K. J., Yang, W. I., Lee, H.Y., Int. J. Legal Med. 2013, 127, $35-43$

This article is protected by copyright. All rights reserved. 


\section{Figure legends}

Figure 1. DNA methylation profiling results of part 1 conducted with the final SBE products of the multiplex methylation $\mathrm{SNaPshot}$ reaction. DNA methylation was recorded as a percentage value by dividing nucleotide $\mathrm{G}$ intensity by nucleotide $\mathrm{G}$ plus nucleotide $\mathrm{A}$.
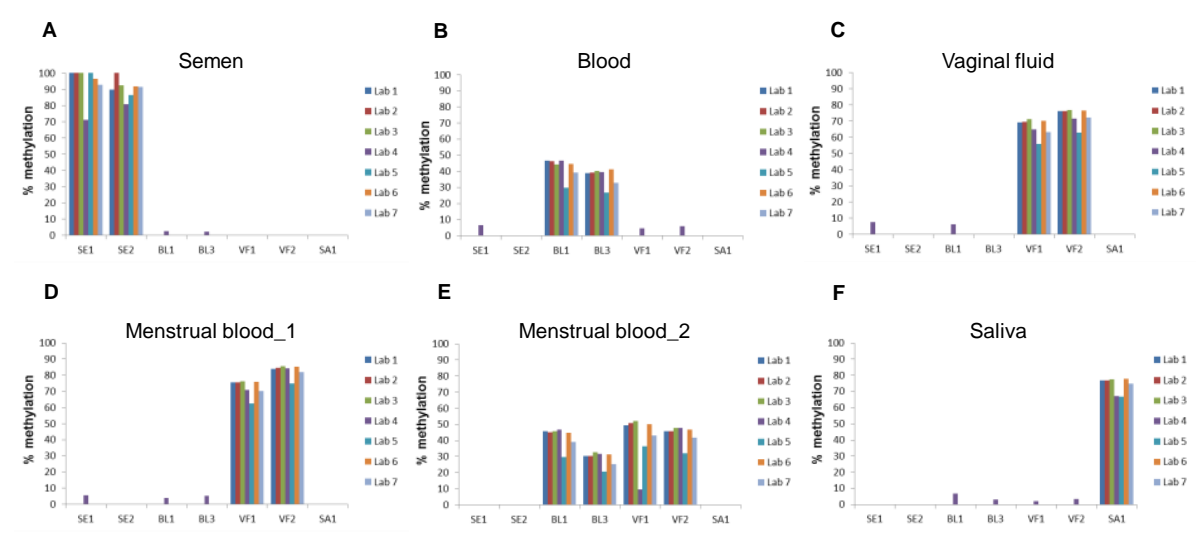

This article is protected by copyright. All rights reserved. 
Figure 2. DNA methylation profiling results of part 2 conducted with bisulfite converted DNA. Part 2 results show the proficiency of each laboratory in SBE reaction analysis. (Un) indicates samples provided with unspecified body fluid origin.
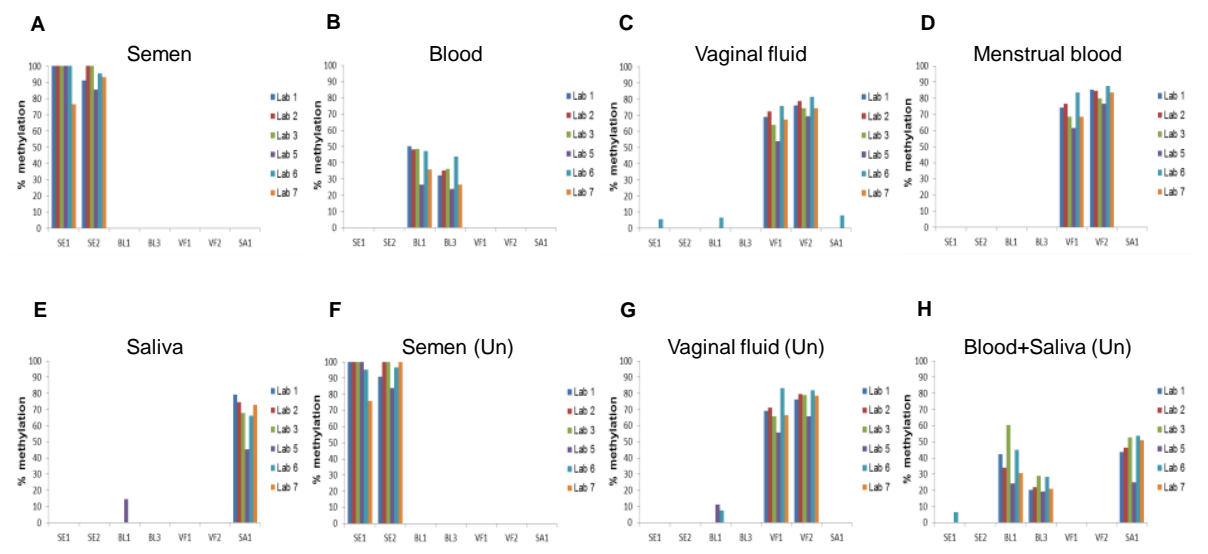

This article is protected by copyright. All rights reserved. 
Figure 3. DNA methylation profiling results of part 3 conducted with genomic DNA. Part 3 results show the proficiency of each laboratory in bisulfite conversion. (Un) indicates samples provided with unspecified body fluid origin.
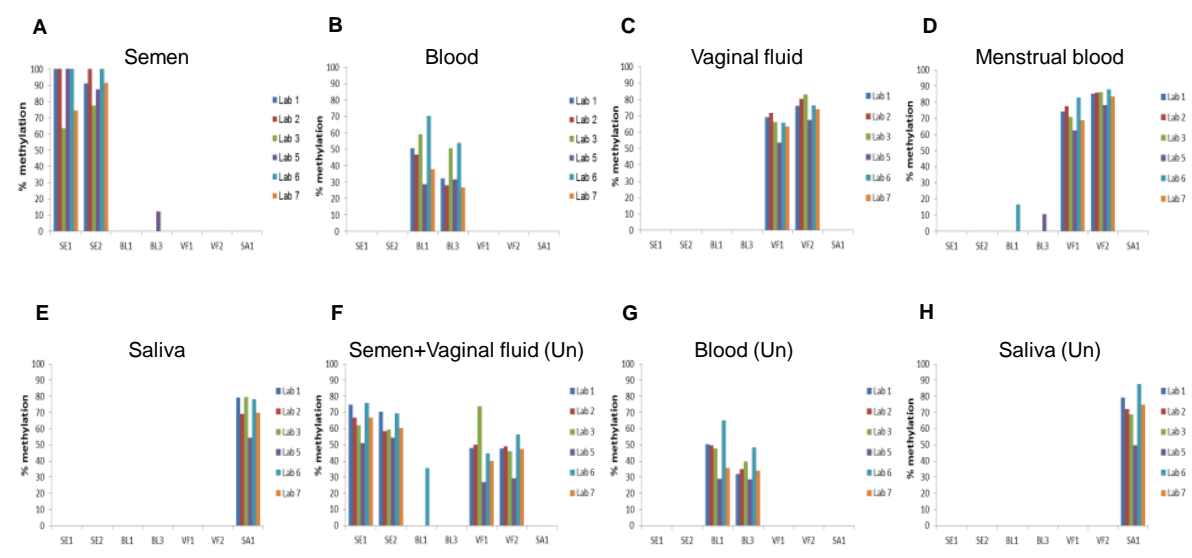

This article is protected by copyright. All rights reserved. 
Figure 4. DNA methylation profiling results of part 4 with body fluid samples. Part 4 results show the proficiency of each laboratory in the entire DNA methylation-based body fluid typing procedure ranging from DNA extraction to capillary electrophoresis. (Un) indicates samples provided with unspecified body fluid origin.

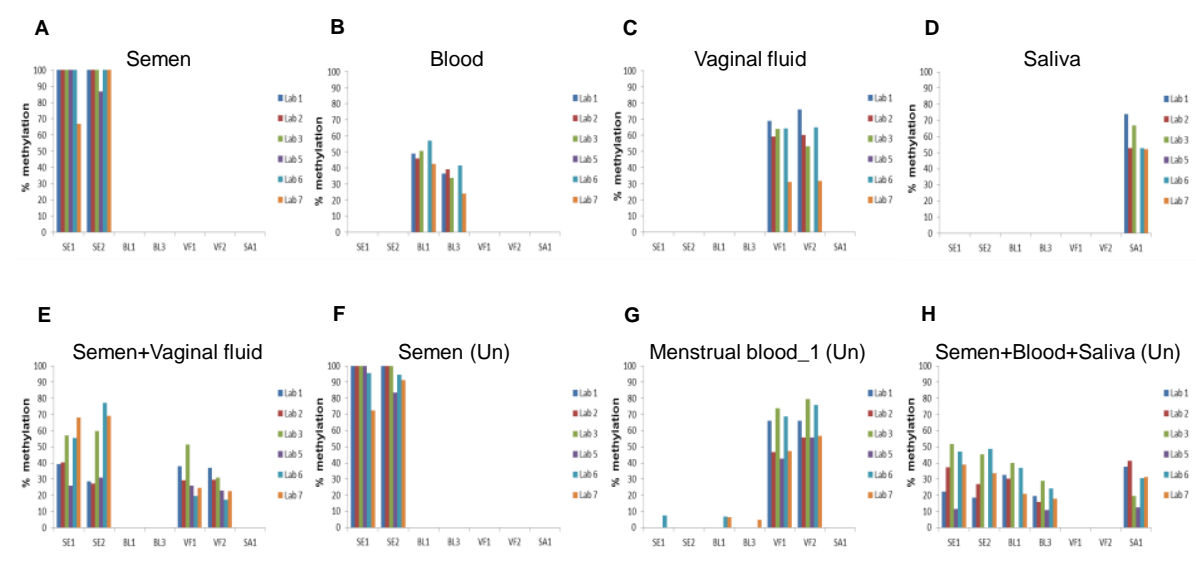

This article is protected by copyright. All rights reserved. 
1 Table 1. Overview of the samples and experiments required in each part of the collaborative exercise

\begin{tabular}{|c|c|c|}
\hline Part & Samples & Required experiments \\
\hline 1 & $\begin{array}{c}\text { Purified }^{a} \text { SBE(single-base extension reaction) } \text { product }^{b} \\
6 \text { samples : for each cell type } \\
\text { cell type indicated }\end{array}$ & Capillary electrophoresis \\
\hline 2 & $\begin{array}{l}\text { Bisulfite converted DNA } \\
5 \text { samples : for each cell type }{ }^{c}, \text { single source samples, } \\
\text { cell type indicated } \\
2 \text { samples : single source samples, unspecified cell type } \\
1 \text { sample : mixture of two body fluids, unspecified cell type }\end{array}$ & $\begin{array}{l}\text { Multiplex PCR, Multiplex SBE, } \\
\text { Capillary electrophoresis }\end{array}$ \\
\hline 3 & $\begin{array}{l}\text { Genomic DNA } \\
5 \text { samples : for each cell type }{ }^{\mathrm{e}} \text {, single source samples, } \\
\text { cell type indicated } \\
2 \text { samples : single source samples, unspecified cell type } \\
1 \text { sample : mixture of two body fluids, unspecified cell type }\end{array}$ & $\begin{array}{l}\text { Bisulfite conversion, } \\
\text { Multiplex PCR, Multiplex SBE, } \\
\text { Capillary electrophoresis }\end{array}$ \\
\hline 4 & $\begin{array}{l}\text { Body fluid swabs } \\
4 \text { samples : for each cell type }{ }^{\dagger}, \text { single source samples, } \\
\text { cell type indicated } \\
1 \text { sample : mixture of two body fluids, cell type indicated } \\
2 \text { samples : single source samples, unspecified cell type } \\
1 \text { sample : mixture of body fluids, unspecified cell type }\end{array}$ & $\begin{array}{l}\text { DNA extraction, DNA quantification, } \\
\text { Bisulfite conversion, } \\
\text { Multiplex PCR, Multiplex SBE, } \\
\text { Capillary electrophoresis }\end{array}$ \\
\hline
\end{tabular}

Received: 01-06-2016; Revised: 01-06-2016; Accepted: 10-07-2016

This article has been accepted for publication and undergone full peer review but has not been through the copyediting, typesetting, pagination and proofreading process, which may lead to differences between this version and the Version of Record. Please cite this article as doi: 10.1002/elps.201600256.

This article is protected by copyright. All rights reserved. 
${ }^{a}$ Purified with SAP-Recombinant enzyme

${ }^{\mathrm{b}}$ Multiplex SBE reaction product

Semen, blood, vaginal fluid, menstrual blood and saliva

Bisulfite converted DNA using the Sigma's Imprint ${ }^{\circledR}$ DNA modification kit

Genomic DNA extracted using the Qiagen's QIAamp DNA Mini kit and quantified using the ABI Quantifiler ${ }^{\circledR}$ Duo DNA Quantification kit

Semen, blood, vaginal fluid and saliva

This article is protected by copyright. All rights reserved. 